\title{
THE ROLE OF DIRECTORATE GENERAL OF CUSTOMS AND EXCISE IN HANDLING COVID-19 PANDEMIC AS A TRADE FACILITATOR AND INDUSTRIAL ASSISTANCE IN INDONESIA
}

\author{
Ahmad Romadhon ${ }^{1 *}$ \\ ${ }^{1}$ Directorate General of Customs and Excise, Sidoarjo \\ E-mail: ahmadromadhon246.ar@gmail.com
}

\begin{abstract}
This paper seeks to examine the role of Directorate General of Customs and Excise as an institution under The Ministry of Finance of Indonesian Republic in its function as a trade facilitator and industrial assistance in handling Corona Viruses Disease 2019 (Covid-19) pandemic in Indonesia. As covid-19 has been made crisis in almost every country around the world, it is being concerned about the shortage of health supplies that needed to prevent the deployment of the viruses and for the treatment process. Besides that, company continuity during pandemic was also threatened due to the decrease of demand and activities. Having function in international trade and industrial assistance, Directorate General of Customs and Excise are capable in helping central government by using its function as a trade facilitator and industrial assistance with (two) major key, first is helping maintain the availability of the health supplies that needed in handling covid-19 pandemic, and the second is providing additional incentives for companies of bonded zone facilities and/or companies that receive ease of import for export purpose facility.
\end{abstract}

Keywords: Covid-19 Pandemic, Directorate General of Customs and Excise, Trade Facilitator and Industrial Assistance

\section{INTRODUCTION}

Covid-19 pandemic disclose the effectiveness of the government policy. The government is facing a new national threat that effect almost all the sector in the country starting from public health, economy, social life, and even international relationship. The government forced to assign public and private sector policy as fast as possible yet remain effective to reduce the spread of the viruses and keep the economy of the nation remain stable.

"The role of customs agencies is vital thus the world customs organization's (WCO's) harmonized system convention remains a crucial element of the global trading system" Harrison, et al., (on Edirisinghe, L. \& Jayathilake, S., 2014).

Central government has an important role in the national economy that can be realized in providing fiscal incentives to increase growth and protect domestic investment. Stand as an industrial assistance and trade facilitator in international trade, making Directorate General of Customs and Excise as one of the main institution in charge of an assignment of policy which is expected to give positive wide impact in order to mitigate critical risk that has been effect by covid-19 pandemic. 
Response to the covid-19 pandemic, Directorate General of Customs and Excise run few numbers of programs in occasion to handle the pandemic crisis and also support the economic recovery of Indonesia.

Many researches focused on prescribe the role of the central government and health workers in handling covid-19 pandemic yet put aside one of the main actor in international trade that maintaining health supplies inside the country and also give a wide effect to sustain the continuity of companies. Focused on the flow of goods in international trade will make it more clear that one of the key to solving pandemic crisis is the availability of the health supplies and the continuity of company life.

There were many policies that had been used by the government, particularly Directorate General of Customs and Excise in handling this pandemic, yet this paper only focused on two major policies. First is Import duty exemption of goods that needed in handling covid-19 pandemic and the second is additional incentives for companies of bonded zone facilities and/or companies that receive ease of import for export purpose facility for handling Covid-19 pandemic. Therefore, the objective of this research is to examine the role of Directorate General of Customs and Excise in handling the pandemic using its function as a trade facilitator and industrial assistance.

\section{THEORY REVIEW}

\section{1. COVID-19 PREVENTION AND THE PROBLEM}

According to Su, V. Y. -F. et al.; (2020), on the basis of Taiwan's invaluable experience in the prevention and control of epidemics, there are 2 approaches that believed among the main factors contributing to the success of taiwan in limiting the spread of Covid-19. The first is to wear face masks during epidemic while keeping the price of face masks low by controlling the manufacture and sale of face masks and the second is the affordability of public access on screening tests and medical care for covid-19.

Become crucial point in prevention of covid-19, personal protective equipment supplies such as masks, and gloves, etc. threatened to be decrease caused by high usage around the world. "During the current pandemic of the novel corona virus disease 2019 (Covid-19), a significant shortage of personal protective equipment (PPE) has been perceived in many countries of the world, creating challenges in providing medical services. Sai, S. et al., (2020)

\section{2. THE ROLE OF CUSTOMS}

Widdowson D. (2007), state that Traditionally, customs has been responsible for implementing a wide range of government policies, spanning area as diverse as revenue collection, trade compliance and facilitation, interdiction of prohibited substances, protection of cultural heritage and enforcement of intellectual property laws, which in developing and least developed countries main focus for their customs authority is revenue collection, on the other hand there is an increasing focus on border protection, with particular emphasis on the enforcement of import and export prohibitions and restrictions.

Directorate General of Customs has a very important role in driving the national economy that manifested in form of state's revenue collection to finance national development, provision of trade facilitation, giving fiscal incentives to enhance growth and domestic investment, as well as protecting public from the inclusion of a harmful items for security and interfere public health (Al Bram; 2013).

\section{3. World Customs Organization option to mitigate the effects of the Covid-19 Pandemic}

According to World customs organization (2020), in order to mitigate the effects of the covid19 pandemic, customs can contributed in facilitating the cross-border movement of relief and 


\section{JOURNAL OF MANAGEMENT, ACCOUNTING, GENERAL FINANCE AND INTERNATIONAL ECONOMIC ISSUES (MARGINAL) \\ VOLUME 1 ISSUE 2 (2022)}

essential supplies, supporting the economy and sustaining supply chain continuity, protecting staff, and protecting society.

\section{RESEARCH METHOD}

Data in this research was combine from journals, articles, news, books, etc. This research is using literature study with descriptive analysis method. All the data that have been collected was reviewed, analysed, then serve in narrative form.

\section{RESULT AND DISCUSSION}

Directorate general of customs and excise is using fiscal policy in carrying out its role as a trade facilitator and industrial assistance. Instrument that has been made expected to effected importation quantity of goods that needed in handling covid-19 pandemic and also helping companies' continuity to remain stable during covid-19 pandemic.

\section{1. Import duty exemption of goods that needed in handling covid-19 pandemic}

Through regulation of the Minister of Finance of The Republic of Indonesia number 34/PMK.04/2020, 83/PMK.04/2020, 149/PMK.04.2020, and 92/PMK.04/2021, Directorate General of Customs and Excise provide convenience for importer to import goods that needed in handling covid-19 pandemic.

On imported goods for the purpose of handling covid-19 pandemic, given customs facilities and/or excise tax and other tax in the form of import duty exemption and/or excise, no value added tax, no sales tax on luxury goods, and no corporate income tax of import activities (income tax 22th article).

During the period from January 1 to August 31 2021, total import value of medical devices handling covid-19 that received this facility reached Rp 5.52 trillion. From this value, the exemption from import duties is worth Rp 300 billion, VAT exemption at Rp 553 billion, and the exemption from corporate income tax of import activities is Rp 207 billion. During the pandemic in 2020 to 2021 , there were changes in the quantity types of the goods in this facilities. These change were the results of continuous analysis by directorate general of customs and excise.

Table 1

Number of Types of Goods in The Import duty exemption of goods that needed in handling covid-19 pandemic

\begin{tabular}{|c|c|c|}
\hline No & Exemption Regulation & Number of types of goods \\
\hline 1 & 34/PMK.04/2020 & 73 \\
\hline 2 & 83/PMK.04/2020 & 49 \\
\hline 3 & 149/PMK.04.2020 & 21 \\
\hline 4 & 92/PMK.04/2021 & 26 \\
\hline
\end{tabular}

4. 2. Additional Incentives for companies of bonded zone facilities and/or companies that receive ease of Import for export purpose facility for handling Covid-19 pandemic

The economic impact due to the covid-19 pandemic may result of the risks that the company will reduce production activities or even stop operating. This risk include of bonded zone facilities and company that receive facilities of import for export purpose, which will result of the decrease of export activities. In addition, related to workforce, there is a risk of employee reduction. Response to this risk, Directorate General of Customs and Excise assign additional incentives for this facility which included in regulation of The Minister of Finance of The Republic of Indonesia number 31/PMK.04/2020. 
Incentives that include in this regulation are:

1) Incentives for companies recipient of bonded zone

Table 2

Before and After Additional Incentives for companies recipient of bonded zone

\begin{tabular}{|c|l|l|}
\hline No & \multicolumn{1}{|c|}{ Before } & \multicolumn{1}{|c|}{ After Additional Incentives } \\
\hline 1 & $\begin{array}{l}\text { Sales of domestic products are } \\
\text { limited to a quota of 50\% of the } \\
\text { export value }\end{array}$ & $\begin{array}{l}\text { Sales of domestic products are allowed } \\
\text { without reducing the sales quota for the } \\
\text { current year }\end{array}$ \\
\hline 2 & $\begin{array}{l}\text { Physical examinations are carried } \\
\text { out randomly based on risk } \\
\text { management, carried out directly by } \\
\text { officers, and self-service } \\
\text { examinations is only allowed for } \\
\text { independent companies of bonded } \\
\text { zone facility }\end{array}$ & $\begin{array}{l}\text { Physical inspection of the entry/export of } \\
\text { goods is carried out selectively, utilizing } \\
\text { information technology, and if the area is } \\
\text { lockdown then the companies can be } \\
\text { granted self-service approval }\end{array}$ \\
\hline 3 & $\begin{array}{l}\text { Paying import duties and import tax } \\
\text { in general import provisions }\end{array}$ & $\begin{array}{l}\text { Suspension of import duties and import } \\
\text { taxes on the entry of masks, Personal } \\
\text { Protective Equipment, etc, as long as it } \\
\text { used in the bonded zone }\end{array}$ \\
\hline
\end{tabular}

\section{2) Incentives for companies that receive facilities of import for export purpose}

Table 3

Before and After Additional Incentives for that receive facilities of import for export purpose

\begin{tabular}{|c|l|l|}
\hline No & \multicolumn{1}{|c|}{ Before } & \multicolumn{1}{|c|}{ After Additional Incentives } \\
\hline 1 & $\begin{array}{l}\text { Import of goods from within the } \\
\text { country in order to be processed for } \\
\text { export purposes is subject to value } \\
\text { added tax or value added tax and } \\
\text { sales tax on luxury goods }\end{array}$ & $\begin{array}{l}\text { Import of goods from within the country in } \\
\text { order to be processed for export purposes is } \\
\text { not subject to value added tax or value added } \\
\text { tax and sales tax on luxury goods }\end{array}$ \\
\hline 2 & $\begin{array}{l}\text { It is not allowed to submit } \\
\text { production results to be processed } \\
\text { and/or combine with companies } \\
\text { recipient of bonded zone or even } \\
\text { small and medium industry that }\end{array}$ & $\begin{array}{l}\text { Allowed to deliver production results to be } \\
\text { processed and/or combined with companies } \\
\text { of bonded zone facility product or to small } \\
\text { and medium companies that receive } \\
\text { receive facilities of import for } \\
\text { export purpose products }\end{array}$ \\
\hline 3 & $\begin{array}{l}\text { Companies that receive facilities of } \\
\text { import for export purpose is not } \\
\text { allowed to sell products } \\
\text { domestically and companies that import for export purpose } \\
\text { receive facilities of import for } \\
\text { export purpose in small and medium } \\
\text { industry class is only allowed to sell } \\
\text { products domestically as much as } \\
\text { 25\% of the previous year's export }\end{array}$ & $\begin{array}{l}\text { Companies that receive facilities of import } \\
\text { for export purpose are allowed to sell } \\
\text { products domestically and companies that } \\
\text { receive facilities of import for export } \\
\text { purpose in small and medium industry class } \\
\text { allowed to sell products domestically at a } \\
\text { maximum 50\% of the previous year's export }\end{array}$ \\
\hline
\end{tabular}




\section{JOURNAL OF MANAGEMENT, ACCOUNTING, GENERAL FINANCE AND INTERNATIONAL ECONOMIC ISSUES (MARGINAL) \\ VOLUME 1 ISSUE 2 (2022)}

\begin{tabular}{|c|l|l|}
\hline No & \multicolumn{1}{|c|}{ Before } & \multicolumn{1}{|c|}{ After Additional Incentives } \\
\hline 4 & - & $\begin{array}{l}\text { Companies that receive facilities of import } \\
\text { for export purpose and companies that } \\
\text { receive facilities of import for export } \\
\text { purpose in small and medium industry class } \\
\text { can deliver production results for the } \\
\text { handing of the covid-19 pandemic to the } \\
\text { government or people who obtain import } \\
\text { duty and tax exemptions in the country } \\
\text { without reducing local sales quotas }\end{array}$ \\
\hline
\end{tabular}

According to Directorate General of Customs and Excise (2020), as much 326 companies have been using this additional incentive during pandemic in 2020, and companies of bonded zone facility and companies that receive facilities of import for export purpose contributed export foreign exchange up to Rp 62 billion in 2020 which is $40,97 \%$ from national export foreign exchange in Indonesia at an annual year that is $\mathrm{Rp} 152$ billion.

From the explanation above, it can be concluded that Directorate General of Customs and Excise do have role in handling covid-19, particularly in helping to maintain the availability of the health supplies which needed in covid-19 pandemic. In the reduction of the goods, it can assign fiscal policy to encourage importer to increase import quantity. Besides it is also capable of helping the companies of bonded zone facility and companies that receive facilities of import for export purpose during covid-19 pandemic.

\section{CONCLUSION}

Covid-19 pandemic has been causing dire impacts to many sectors in Indonesia, not only it made crisis in health sector but also economic and even social sector. Directorate general of customs and excise has been proven to have major role in handling covid-19 pandemic.

Having regulatory responsibility at the point of international trade, make it capable of using various government policies, which not only used as a traditionally purpose as a revenue collection, etc. but also fulfilling its role as a trade facilitator and industrial assistance.

Using its function as a trade facilitator, it capable to provide import duty and import taxes exemption that up to 73 kind of goods which worth Rp 5.52 trillion (from 01 January 2021 to 31 August 2021), and as an industrial assistance it helping 326 companies which affected by covid-19 pandemic by providing additional incentives during this pandemic.

Implementation of these two major policies was also appropriate with world customs organization option to mitigate the effects of the covid-19 pandemic by contributed in facilitating the cross-border movement of relief and essential supplies, supporting the economy and sustaining supply chain continuity, protecting staff, and protecting society.

\section{REFERENCES}

Edirisinghe, L. \& Jayathilake, S., (2014). Frontier Logistics Performance in Sri Lanka-The Role Play of The Customs, Ratmalana, General Sir John Kotawala Defense University, pp, 424432. https://doi.org/10.2139/ssrn.2965967

Su, V.Y.-F, Yen, Y.-F, Yang, K.-Y, Su, W.-J, Chou, K.-T, Chen, Y-.M, \& Perng, D.-W (2020). Masks and Medical Care:Two Keys to Taiwan's Success in Preventing Covid-19 spread, Travel Medicine and Infectious Disease, 38(101780), 1-2. https://doi.org/10.1016/j.tmaid.2020.101780 
Sai, S. Mohan, G., Arvind, K. B., Ayush L., Afza, A. Banani, P. \& Namrata, S. R. (2020). Personal Protective Equipment During Covid-19 Pandemic: a Narrative Review on Technical Aspects, Experts Review Medical Deevices, 17(12), 1265-1276. https://doi.org/10.1080/17434440.2020.1852079

Widdowson, D. (2007). The Changing Role of Customs: Evolution or Revolution. World customs journal, 1(1), 31-37

Al Bram, H. Djafar. 2013. Customs Facilities (Indirect Tax, Import Duties) in order to Support Industry and Investment. Law Businness Journal, 32(6), 532

Director General of Customs and Excise (2021). Directorate General of Customs and Excise 2020 Performance Report. Directorate General of Customs and Excise.

Timorria, L. F. (2021, September 5). Oxygen and support equipment import value up to Rp 1.2 Trillion . Bisnis.com. https://m.bisnis.com/ekonomibisnis/read/20210909/12/1440180/impor-oksigen-dan-alat-pendukung-capai-rp12-triliun 